\title{
Reproductive biology of Hyla goiana (Anura, Hylidae)
}

\author{
Marcelo Menin ${ }^{1,2}$; Rodrigo A. Silva ${ }^{1} \&$ Ariovaldo A. Giaretta ${ }^{1}$ \\ 1. Laboratório de Ecologia e Sistemática de Anuros Neotropicais, Instituto de Biologia, Universidade Federal de Uberlândia, \\ 38400-902, Uberlândia, MG, Brasil \\ 2. Present address: Coordenação de Pesquisas em Ecologia, Instituto Nacional de Pesquisas da Amazônia, Av. André Araújo 2936, \\ 69011-970, Manaus, AM, Brasil. (menin@inpa.gov.br)
}

\begin{abstract}
Male-male and male-female interactions, reproductive habitat, and vocalizations of Hyla goiana B. Lutz, 1968 a member of $H$. polytaenia species group, are described. Three groups of calling males were surveyed along a small stream, at the Estação de Pesquisa e Desenvolvimento Ambiental de Galheiro, Perdizes municipality, State of Minas Gerais, Brazil. The mean distance between the nearest calling neighbors was $2.7 \mathrm{~m}$, in accordance with an uniform distribution. Clutches (mean 180 eggs) were deposited in the stream, submerged and attached to plants. In two observed courtships the female moved towards a calling male that rapidly clasped her. In the male-male interaction, the males emitted advertisement and encounter calls and then engaged in physical combat. The males have a prepollical fang-like spine on each hand and several of them were observed with scratches on dorsum. The advertisement call consists of alternating harsh notes and a trilled of brief notes. The frequency of the call is lower than that of $H$. aff. polytaenia and $H$. cipoensis B. Lutz, 1968. The clutch characteristics of $H$. goiana are similar to those described for $H$. polytaenia Cope, 1870 and $H$. cipoensis.
\end{abstract}

KEYWORDS. Anura, Hyla, behavior, reproduction, advertisement call.

\section{INTRODUCTION}

Several neotropical hylid frogs have been used as models for the study of territoriality and male-male behavioral interactions including fighting, emission of aggressive calls, and spatial distribution in choruses (CARdoso \& Haddad, 1984; Martins \& Haddad, 1988; BASTOS \& HADDAD, 1995, 1996). The Hyla polytaenia species group includes seven small species (CARAMASCHI $\&$ CRUZ, 2000), and little is known about their reproductive ecology. Here are described male-male and male-female interactions, reproductive habitat, and calls of Hyla goiana B. Lutz, 1968, a member of this group.

\section{MATERIAL AND METHODS}

The study was conducted during the first half of February 2001, at the Estação de Pesquisa e Desenvolvimento Ambiental de Galheiro (EPDA) (approx. $\left.19^{\circ} 12^{\prime} \mathrm{S}, 47^{\circ} 08^{\prime} \mathrm{W}\right)$, Perdizes municipality, State of Minas Gerais, southeastern Brazil. The regional climate is characterized by a rainy/warm summer and dry/mild winter (type AW in the Köppen System, Rosa et al., 1991). The predominant vegetation is Brazilian savanna (cerrado) (AB'SABER, 1977). The field work was conducted from 7:00 to $12: 00 \mathrm{pm}$. Three groups of calling males were surveyed along a $300 \mathrm{~m}$ section of a small stream. The slow flowing stream was about $50 \mathrm{~cm}$ deep and $100 \mathrm{~cm}$ wide; the bottom was muddy.

The frogs were found along the stream edges, which were partially covered with shrubs, grasses, and gallery forest. The calling sites and the position of each male in the vegetation were recorded; its height from the ground, its distance from the edge of the stream, and its distance to the nearest calling male was measured. Each individual was marked by toe clipping (MARTOF, 1953) and measured its snout-vent length (SVL) with calipers ( $0.05 \mathrm{~mm}$ precision). At the beginning of each night, it was recorded the number of calling males. The calling site of each male was marked on a schematic map of the stream. The pattern of spatial distribution of the males was evaluated using nearest neighbor distances in the Dispersion Index (variance/mean) and t-test (BROWER \& ZAR, 1984). To calculate the density and the distance between individuals, it was considered only those segments of stream where males were relatively close together; peripheral males showing distances greater than $30 \mathrm{~m}$ from each other were considered as belonging to a different group.

Interacting individuals encountered during sampling were observed until the end of the interaction. To obtain clutches, two amplectant pairs were kept over night in plastic bags containing water $(1000 \mathrm{ml})$ and plants (leaves of grasses). The clutches obtained were preserved in 5\% formalin in the following morning.

Vocalizations were recorded with a tape recorder (frequency response 50-15 $000 \mathrm{~Hz}$; speed of $19 \mathrm{~cm} / \mathrm{s}$ ) and a condenser microphone (frequency response 100$20000 \mathrm{~Hz}$ ). The calls were analyzed in the Spectrogram 7 software (R. S. Horne, 2002. Spectrogram version 7.2. Visualization Software LLC), using 16 bit resolution, $22 \mathrm{kHz}$ sampling frequency, and FFT with 1024 points. The advertisement call was described according to the call types reported for Hyla aff. polytaenia by HEYER et al. (1990); the vocalization emitted in acoustic interactions was considered an encounter call (Duellman \& Trueb, 1994). Two males and one female were preserved as vouchers specimens (Museu de Biodiversidade do Cerrado, Universidade Federal de Uberlândia, UFU 2271, 2272, 2273). 


\section{RESULTS}

Hyla goiana specimens from the EPDA have the typical longitudinal striped pattern of members of the Hyla polytaenia group (fig. 1). In this population, males averaged $33.6 \mathrm{~mm}(\mathrm{SD}=1.4 ; \mathrm{n}=30$; range $=30.3-35.6)$ in $\mathrm{SVL}$; females were larger, $37.7 \mathrm{~mm}(\mathrm{SD}=0.7 ; \mathrm{n}=3$; range $=37.0$ - 38.3). A total of 30 males were marked and followed $(6,8$, and 16 males in the three groups of calling males) to describe the time they remained in the choruses.

Males called from branches or leaves, often with the axis of their bodies parallel to the ground, from 0.10 to $1.70 \mathrm{~m}$ above the ground $(\mathrm{mean}=0.70 ; \mathrm{SD}=0.35 ; \mathrm{n}=30$ ) and from 0 to $8 \mathrm{~m}$ from the edges of the stream (mean =
1.94; $\mathrm{SD}=2.09 ; \mathrm{n}=30)$. The vocalizations began at dusk, about 7:00 pm, with a peak (15-20 males) around 8:00 pm; scattered vocalizations were heard around the end of the observation period. Most (24) males called from the same site on consecutive nights; six individuals moved, four of them occupied call sites of other males, and two moved to the other side of the stream. The longest observed period a male remained in the chorus was eight nights.

Three clutches were obtained, two in plastic bags and one in the field. The spawn found in the field was submerged (about $2 \mathrm{~cm}$ below the water surface) and was attached to plants at the edge of the stream; those obtained in the laboratory also were attached to plants. The egg masses are nearly spherical, with gelatinous
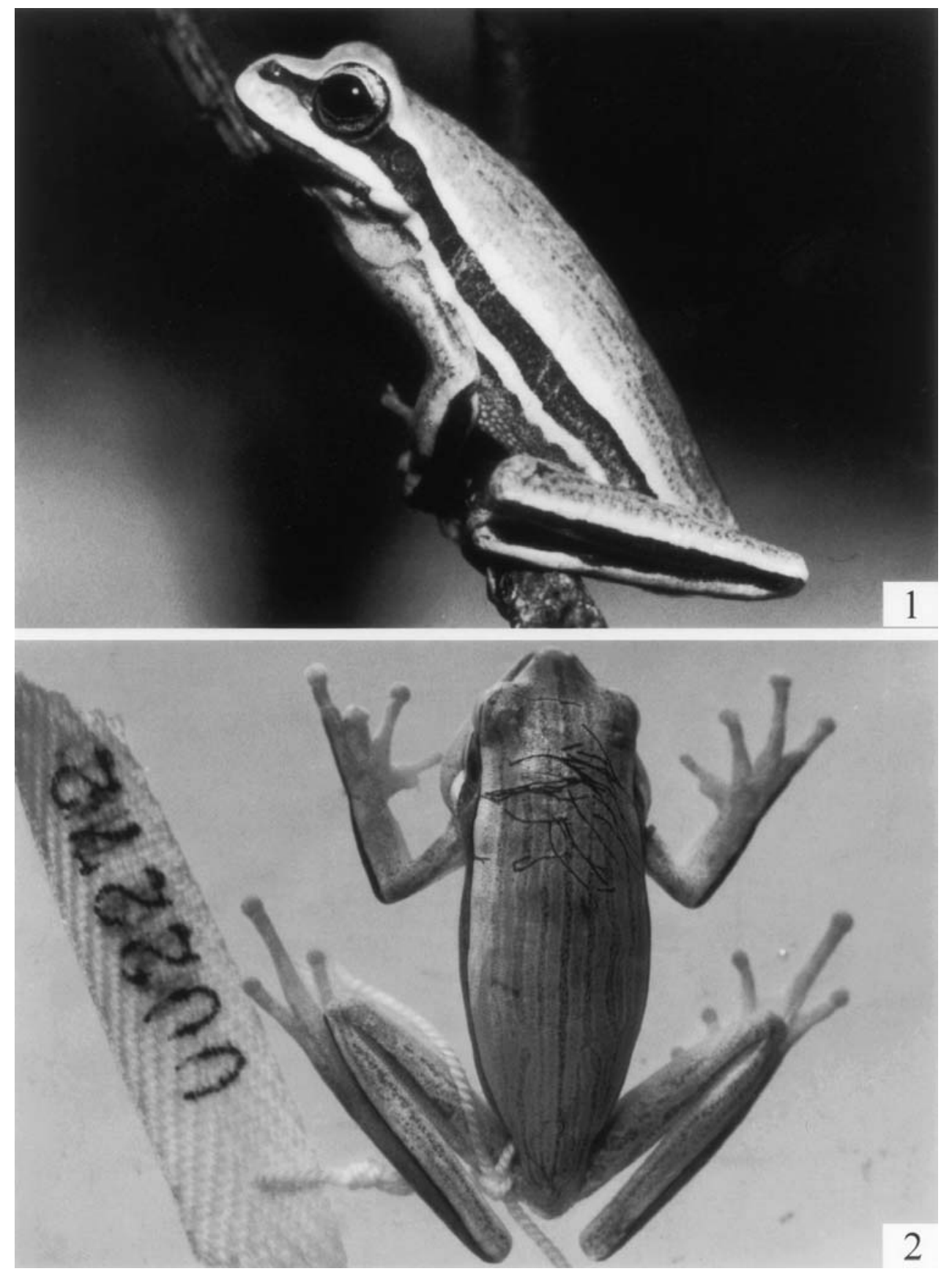

Figs. 1, 2. Hyla goiana B. Lutz, 1968: 1, live adult male; 2, preserved male showing scratches on his dorsum produced during fights (SVL, $34.5 \mathrm{~mm}$ ). 
capsules adhered to each other. Clutch size averaged 180 eggs $(\mathrm{SD}=51 ; \mathrm{n}=3 ;$ range $=126-226)$, mean egg diameter was $1.1 \mathrm{~mm}(\mathrm{SD}=0.12 ; \mathrm{n}=5$; range $=0.94-1.24)$. The eggs are black in the animal pole and light brown in the vegetal pole.

The courtship was observed twice. In both cases, the female moved towards a calling male and stopped about $20 \mathrm{~cm}$ from it; the male moved towards the female and rapidly clasped her. Four pairs in amplexus were found, all between 8:00 and 10:00 pm. The amplexus was axillary. Three pairs remained motionless in amplexus until 12:00 pm, when they were collected. One male-male interaction was noted. The males were $1 \mathrm{~m}$ apart from each other when found, calling from different heights in the vegetation. The lower male moved towards the other male, emitting advertisement and encounter calls; the approach lasted about 50 minutes. When the moving male reached the other male, they fought during two minutes. The males grasped each other, keeping their bellies in contact; they had their arms around each other and their hands on each other dorsum. The intruder displaced the resident and started to call from where the resident male had been; the resident remained motionless and silent about $20 \mathrm{~cm}$ below the fight site. Laboratory analysis revealed that males have a prepollical fang-like spine on each hand and several of them showed scratches on their dorsum (fig. 2).
The mean distance between the nearest calling neighbors was $2.7 \mathrm{~m}(\mathrm{SD}=1.5 ; \mathrm{n}=25)$, distances less than $1 \mathrm{~m}$ were rare. The Dispersion Index was 0.80 , in agreement with an uniform distribution $(\mathrm{t}=4.42 ; \mathrm{df}=$ $24 ; \mathrm{p}<0.05)$. The density of males in vocal activity was $0.16 \mathrm{males} / \mathrm{m}$.

Two call types were recognized in $H$. goiana: advertisement call and encounter call. The advertisement call consists of alternating harsh notes and a trilled of brief notes. The harsh notes (fig. 3) are frequently emitted at the beginning of a sequence, followed by the trill. The harsh notes call had a composite of two notes; call lasting $325 \mathrm{~ms}$ ( $\mathrm{n}=1$ call); the first note had a duration of $140 \mathrm{~ms}$ and the second $90 \mathrm{~ms}$. The interval between notes was $90 \mathrm{~ms}$. The first note ranged from 2295 to $3280 \mathrm{~Hz}$, and the second from 2925 to $3694 \mathrm{~Hz}$. The trilled call (fig. 4) has three to five notes (mean $=4 ; \mathrm{SD}=1 ; \mathrm{n}=4$ ); call lasting from $150-270 \mathrm{~ms}($ mean $=213.75 ; \mathrm{SD}=49.22 ; \mathrm{n}=4)$. One note varied between 20 and $45 \mathrm{~ms}$ (mean $=33.12 ; \mathrm{SD}=$ $6.80 ; \mathrm{n}=16$ ). The frequency of each note of the trill was variable, increasing towards the end of the call. The first note ranged from 2230 to $3296 \mathrm{~Hz}$ and the last note, from 2342 to $3900 \mathrm{~Hz}$. The encounter call (not recorded) occurred when males are close together; and was sometimes emitted alternately with the advertisement call.
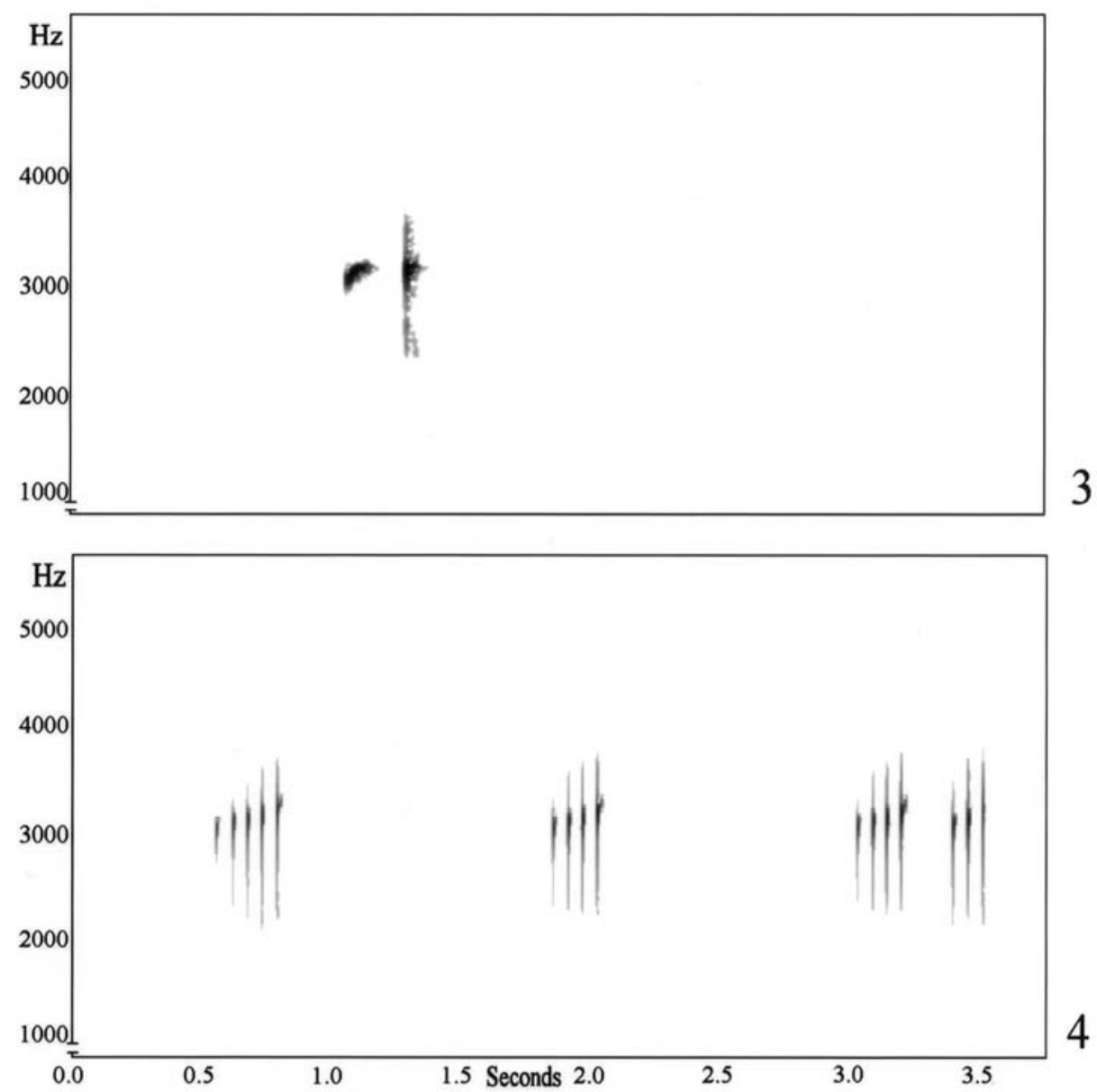

Figs. 3, 4. Audiospectrograms of calls of Hyla goiana: 3, harsh notes; 4, trilled call. Tape AAG-022, 19 January 2000. Water and air temperature, $22^{\circ} \mathrm{C}$. 


\section{DISCUSSION}

Males of Hyla goiana call from marginal vegetation of water bodies, like other species of the Hyla polytaenia group (HADDAD et al., 1988; CARDOSO et al., 1989; HEYER et al., 1990), but in the group, only H. goiana is known to lay eggs in flowing water.

Male-male aggressive behavior has never been reported before for a member of this group. In H. goiana, the territorial behavior, such as fights and territorial calls, is performed around the calling sites. Aggressive behavior related to territoriality has been reported in a number of hylids, and most have territorial calls, $H$. minuta Peters, 1872 (CARdoso \& Haddad, 1984), H. wavrini Parker, 1936(Martins \& MoreIRA, 1991), H. elegans Wied-Neuwied, 1824 (BASTOS \& HADDAD, 1995), and H. faber Wied-Neuwied, 1821 (MARTINS et al., 1998). Among frogs, the presence of scratches on the dorsum is indicative of male-male agonistic interactions, as seen among hylid frogs in the $H$. boans group (MARTINS et al., 1998). The scratches observed on the dorsum of males of $H$. goiana are caused by the prepollical spines of rival males during fights. Other species of the $H$. polytaenia group that have prepollical spines include $H$. polytaenia (LUTZ, 1973), H. leptolineata Braun \& Braun, 1977 (pers. obs.), and H. phaeopleura Caramaschi \& Cruz, 2000 (CARAMASCHI \& CRuz, 2000), and territorial behavior, such as that we described, is expected in these species.

A low number of territorial interactions was observed among males of $H$. goiana, and this may be due to the low density of males in choruses. The territoriality, with emission of vocalizations, may prevent physical combats (WELLS, 1977; MARTINs et al., 1998) and promote regular spacing between calling males. For frogs, the maintenance of individual calling sites may facilitate pairing and reduces the risks of disturbance by satellite males (WELLS, 1977; BAstos \& HADDAD, 1995, 1999; MARTINs et al., 1998). Males of $H$. goiana move towards the approaching females and amplex with them quickly, a behavior probably related to the prevention of clasping by satellite males (BASTOS \& HADDAD, 1996), as reported for $H$. minuta and $H$. elegans ( respectively, HAdDAD \& CARdoso, 1992 and Bastos \& HAdDAD, 1996). Remaining at the calling site after amplexus, which has also been observed for $H$. elegans, may be a strategy to avoid the interception of coupling by males performing active search for females (BASTOS \& HADDAD, 1996).

The clutch characteristics of $H$. goiana are similar to those described by LuTz $(1948,1973)$ for $H$. polytaenia, a gelatinous mass adhering to underwater vegetation, containing ca. 200 dark eggs with a $1 \mathrm{~mm}$ diameter, and $H$. cipoensis B. Lutz, 1968 (ETEROVICK et al., 2002).

The advertisement call recorded in this study is similar to that reported for H. goiana in Goiás, Brazil (GuIMARÃES et al., 2001). An advertisement call composed of two distinct types of notes (harsh notes and trill), has been reported for $H$. aff. polytaenia (HEYER et al., 1990). The frequency of the advertisement call of $H$. goiana is lower than that of $H$. aff. polytaenia (HEYER et al., 1990) and H. cipoensis (HADDAD et al., 1988). The variable number of pulses in the trill has also been reported for H. cipoensis (HADDAD et al., 1988). The call parameters support specific distinction among these species.
Acknowledgments. To Companhia Energética de Minas Gerais (CEMIG) for the facilities at the EPDA de Galheiro; CAPES for the fellowship to M. Menin; Dr. J. M. Vielliard for the loan of the recording devices; M. N. de C. Kokubum helped in the field work; B. Marshall for abstract review; R. I. Combrie (Smithsonian Institution) provided many useful suggestions in the manuscript.

\section{REFERENCES}

AB'SABER, A. N. 1977. Os domínios morfoclimáticos na América do Sul. Primeira aproximação. Geomorfologia, São Paulo, 52:1-22.

Bastos, R. P. \& Haddad, C. F. B. 1995. Vocalizações e interações acústicas em Hyla elegans (Anura, Hylidae) durante a atividade reprodutiva. Naturalia, São Paulo, 20:165-176.

1996. Breeding activity of the neotropical treefrog Hyla elegans (Anura, Hylidae). Journal of Herpetology, St. Louis, 30(3):355-360.

1999. Atividade reprodutiva de Scinax rizibilis (Bokermann) (Anura, Hylidae) na Floresta Atlântica, sudeste do Brasil. Revista Brasileira de Zoologia, Curitiba, 16(2):409-421.

Brower, J. E. \& ZAR, J. H. 1984. Field \& laboratory methods for general ecology. 2. ed. Dubuque, W. M. C. Brown. 288 p.

Caramaschi, U. \& Cruz, C. A. G. 2000. Duas espécies novas de Hyla Laurenti, 1768 do Estado de Goiás, Brasil (Amphibia, Anura, Hylidae). Boletim do Museu Nacional, Nova Série, Zool., Rio de Janeiro, 422:1-12.

Cardoso, A. J.; Andrade, G. V. \& Haddad, C. F. B. 1989. Distribuição espacial em comunidade de anfíbios (Anura) no sudeste do Brasil. Revista Brasileira de Biologia, Rio de Janeiro, 49(1):241-249.

Cardoso, A. J. \& Haddad, C. F. B. 1984. Variabilidade acústica em diferentes populações e interações agressivas de Hyla minuta (Amphibia, Anura). Ciência e Cultura, São Paulo, 36(8): 1393-1399.

Duellman, W. E. \& Trueb, L. 1994. Biology of amphibians. Baltimore, The Johns Hopkins University. 670p.

Eterovick, P. C.; Barros, I. S. \& Sazima, I. 2002. Tadpoles of two species in the Hyla polytaenia species group and comparison with other tadpoles of Hyla polytaenia and Hyla pulchella groups (Anura, Hylidae). Journal of Herpetology, St. Louis, 36(3):512-515.

Guimarães, L. D.; Lima, L. P. et al. 2001. Vocalizações de espécies de anuros (Amphibia) no Brasil Central. Boletim do Museu Nacional, Nova Série, Zool., Rio de Janeiro, 474:1-14.

Haddad, C. F. B.; Andrade, G. V. \& Cardoso, A. J. 1988. Anfíbios anuros no Parque Nacional da Serra da Canastra, Estado de Minas Gerais. Brasil Florestal, Brasília, 64:9-20.

Haddad, C. F. B. \& CARdoso, A. J. 1992. Elección del macho por la hembra de Hyla minuta (Amphibia: Anura). Acta Zoologia Lilloana, Tucumán, 41:81-91.

Heyer, W. R.; Rand, A. S. et al. 1990. Frogs of Boracéia. Arquivos de Zoologia, São Paulo, 31(4):231-410.

Lutz, B. 1948. Ontogenetic evolution in frogs. Evolution, Lawrence, 1:29-39.

1973. Brazilian species of Hyla. Austin, University of Texas. 260p.

Martins, M. \& Haddad, C. F. B. 1988. Vocalizations and reproductive behavior in the smith frog, Hyla faber Wied (Amphibia: Hylidae). Amphib-Reptilia, Leiden, 9:49-60.

Martins, M. \& Moreira, G. 1991. The nest and the tadpole of Hyla wavrini Parker (Amphibia, Anura). Memórias do Instituto Butantan, São Paulo, 53(2):197-204.

Martins, M.; Pombal, J. P., JR. \& Haddad, C. F. B. 1998. Escalated aggressive behaviour and facultative parental care in the nest building gladiator frog, Hyla faber. AmphibReptilia, Leiden, 19:65-73.

Martof, B. S. 1953. Territoriality in the green frog, Rana clamitans. Ecology, Washington, 34(1):165-174.

Rosa, R.; Lima, S. C. C. \& Assunção, W. L. 1991. Abordagem preliminar das condições climáticas de Uberlândia (MG). Sociedade e Natureza, Uberlândia, 3:91-108.

WeLLS, K. D. 1977. The social behaviour of anuran amphibians. Animal Behaviour, London, 25:666-693. 